\title{
Assessment of Public Services Quality in Libya
}

\author{
Dr. Ibrahim Noureddin Kamba, Dr. Hasan M. Elarabi Elsharif \\ Misurata University-Libya \\ Haitham Institute of Administrative, Financial Sciences \& Computer \\ Misrata -Libya
}

\begin{abstract}
One of the main dimensions of good governance, which was adopted by the World Bank, is to ensure government provides quality services to its citizens. This dimension is very essential for the implementation of government policies and programs. For this reason, the government has to be accountable to all of their people about their services if their quality is not good. This study adopted quantitative method for primary data collection through questionnaire survey. The results from the data which was gathered from the Libyan people revealed that the Libyan people disagree with the rule of law as it does not enhance provision of good quality services, and they have no trust for the current laws by the government because they are not accountable. The reasons for their views were due to the fact that most of the laws are not just laws. The study recommended that there is need to ensure the independence of the legislative institution via the constitution of the state, and also ensure the independence of the judiciary in order to enhance the ability of the institution to work freely without pressure from the government.
\end{abstract}

Keywords: Public services, quality, services quality, Libya

\section{Introduction}

The provision of quality public services has become one of the most important rights the citizens are demanding the government to provide. In order to get these rights to the citizens, there should be just laws to ensure accountability from the government or any institution to protect their rights. The existence of laws is not an objective but rather a means to secure and maintain rights.

In the new era in Libya, all laws must have gained the desirability of citizens. This is because in the previous and the present time, they have not been impeded from getting their rights. In addition, failure of accountability from the government and men of authority has contributed to the spread of corruption in the government. Thus, this hinders the provision of service to citizens and this is what the study seeks to explain.

In the context of decentralization, public services should be more responsive towards the interests of the public. The paradigm of public service should evolve from a service that is centralistic towards a service that focuses more on consumer satisfaction-oriented governance (Mohammad, 2003). Good public services will create a more conducive business climate and also appeal to investors to invest in Libya. This is due to the ease and reliability of services. The provision of reliable public services may also have an impact on the public's trust towards the government.

\section{Public Services}

A public service organization aims to create public value and co-produce social outcomes. This is the aim of the governing bodies on behalf of the public. In practice, the role of governing bodies is complex and diverse. The governing body's role is to serve the public interest and not the interests of any particular group among those affected by its work. In other words, the fundamental raison d'etre of governments is the delivery of services to its people. These services are mainly provided through governmental agencies such as public transportation, public education, social services, fire services, and health care. Nonetheless, the defining of the public interest can be difficult. There are likely to be many different publics, with different interests, which may conflict. Governing bodies have to operate within political systems of direction and control, which is imposed from outside the organization. They must operate within the statutes or other 
directions that are defined. It is the political environment that shapes, and it requires space to shape democratically but with regard to economic realities and the extent of public responsibility. As Richard A. Chapman (2000) has pointed out, 'In liberal democracies, it is the political environment which determines the scope and objectives of the public services; it is the political environment which determines the values to be applied when delivering these services; and it is the political environment which affects the ways public servants work and is the most important factor in the differences between public administration and management or administration in other contexts.'

According to the politics dictionary (2000), the definition of public services is "an essential service that is provided by government such as education or healthcare, or a service that benefits the public in general such as transport". Ulusoy (2004) stated that the public service is a function that is labeled as public service by the parliament due to the fact that this function could not be fulfilled by private sector properly. In addition, public services are abided by privileges and obligations which are different from activities of private initiatives (specific legal regime). Therefore, due to its role in providing public interest, "public authorities have supervision and responsibility provided by the private sector throughout provision process of quality public services".

Parvez (2005) considered service quality as a significant differentiator and the most powerful competitive tool which all the service organizations want to possess. Definitions of service quality hold the result of an evaluation process where customers compare their expectations about a service with their perception of the service to be received (Husin, Romle \& Yusof, 2015; Ahmad, Romle \& Mansor, 2015).

Obviously, the public services quality are provided by the government without charge or simple charge, covering all categories of society, and these services quality are provided by both the local and central government. The public services such as healthcare, education, electricity, water service, infrastructure, and security services are the primary function of government. In recent decades, the governments in the developing countries are becoming more interested when compared with developed countries. This is because the government of developing countries (which Libya is one of them) increases the well-being of citizens through the increase of the quality of the services provided by these governments. Until now, there has never been a well known annual measure of the quality of life scale, and this leads to an increased government attention to public services and delivery of public services to the citizens.

Furthermore, the access to quality public services requires governments to have number of elements that will aid the provision of public services. The adopting of good governance indicators by the government will ensure adherence to standards of good governance, which qualifies them to be able to provide good service to citizens. Hence, any weakness in one or all these factors directly or indirectly has a significant effect on the quality of services provided by the government.

\section{The Problem Statement}

Governance is "good" when a state efficiently provides public goods of necessary quality to its citizens. Hence, states should be assessed on both the quality and the quantity of public services provided to citizens (Rotberg, 2004).

However, this does not exist in Libya as illustrated in the studies of Betamer (2003), PPC (2004), Obeidi (2004), Mustafa and Abu Bakr (2007). Mustafa and Abu Bakr (2008) and Al Haddad (2009) have discussed and clarified that the deteriorating situation has been affecting the quality of public services that are provided by the government and funded through public revenue as revealed in these studies. The realm of public administration regime has also been suffering from inconsistency and instability which relates to the political conflicts. The inconsistency and instability in governing structure of the state has profoundly affected the quality of public service.

Therefore, in this study, the research seeks to attend to the answer to the next question: What is the Libyan people assessment of public service quality provided by Libyan government?

The Objective of Study: To declare Libyan people's assessment of public service quality provided by Libyan government. 
The Significance of Study: Proving a poor public service quality provided by the Libyan government. This is what the Libyan people want to get better and this was the reason for the 2011 revolution.

\section{Methodology of Study}

\section{Sample and Data Collection Method}

In this study, quantitative method is used through the use of questionnaire. A sample size of 250 was used in other studies to measure the satisfaction of the respondents with public services (Ramserook-Manhurrun, 2010; \& Mokhlis, 2011). The questionnaire for this study was administered to 200 respondents, and they constitute the sample size for the study. SPSS was used to analyze the data collected. Descriptive data analysis was used to evaluate the different aspects of the SERVQUAL scale.

The selected respondents cut across public and private sectors establishments within the Libyan state. Majority of the respondents were employees and work with several public and private institutions in Libya. The researchers interpreted the mean score of each item based on five levels, i.e., strongly agree, agree, neutral, disagree, and strongly disagree, for assessing public service quality. Furthermore, the researchers use the mean score of each item based on five levels i.e., Excellent, Good, Neutral, Not good, and bad for assessing quality public service.

To estimate the quality of public services which is provided by the Libyan government to its citizens according to the respondents' perspectives, the researchers asked the respondents about their assessment of the quality public services which is provided by the Libyan government for the citizens. As a result of the table, the general average to answer questions was 3.64 from $1=$ excellent to $5=$ bad. Therefore, this explains that most of the respondents' perspective tends to emphasize that there is dissatisfation from citizens about the quality of public services which is provided by the government.

\section{Table 1. Descriptive Statistics for Respondents' Perspective about the Quality of Public Services}

\begin{tabular}{|l|r|r|}
\hline & Mean & $\begin{array}{r}\text { General } \\
\text { Average }\end{array}$ \\
\cline { 1 - 2 } The quality of health service. & 3.36 & 3.64 \\
\hline The quality of education service. & 3.23 \\
\cline { 1 - 1 } The quality of justice and public security service. & 4.16 \\
\hline The quality of facilities and infrastructure service. & 3.12 \\
\cline { 1 - 2 } $\begin{array}{l}\text { The quality of speed of access to services such as the procurement } \\
\text { official administrative documents. }\end{array}$ & 3.97 \\
\cline { 1 - 2 } The quality of employment provision by the Libyan government. & 3.94 \\
\cline { 1 - 2 } $\begin{array}{l}\text { The quality of accommodation and the unit prices that suit various } \\
\text { income levels. }\end{array}$ & \\
\hline
\end{tabular}

Question 1: What is your assessment of a health service quality which is provided by the Libyan government for the citizens?

The result in Table 1 shows that the mean score for all respondents were as follow. The result of Question 1 reveals that the respondents' mean score stands at 3.36. This result shows that majority of the respondents', $42(21 \%)$ and $44(22 \%)$, answers is bad and not good respectively. Furthermore, this indicated that majority of respondents estimated that the health service quality provided by the Libyan government was not good. This result shows that most of the respondents were of the position that the health service quality which is provided via the Libyan government to the citizens was not satisfactory.

Question 2: What is your assessment of an education quality which is provided by Libyan government for the citizens? 
The mean score for respondents' answer was 3.23. This result shows that majority of the respondents', 26 (13\%), 58 (29\%) of and $60(30 \%)$, answers is good, bad, and not good respectively. This indicated that majority of respondents' evaluation of the quality of education services provided by the Libyan government was not a good service. The result revealed that most of the respondents were dissatisfied about the quality of education services which is being provided by the Libyan government.

\section{Question 3: What is your assessment of the quality of justice and public security service which is provided by the Libyan government for the citizens?}

The result of Question 3 reveals that the respondents' mean score was 3.72. This result shows that majority of the respondents', 68 (34\%) and 44 (22\%), answers is bad and not good respectively. This result implied that the respondents' point of view about the quality of justice and public security services provided by the Libyan government was bad. This also implied that the service provided is not totally dissatisfied.

\section{Question 4: What is your assessment of the quality of facilities and infrastructure which is provided by the Libyan government for the citizens?}

The respondents' mean score was 4.16. This result shows that majority of the respondents', 106 (53\%) and $46(23 \%)$, answers is bad and not good respectively. In addition, this mean that majority of respondents were of the view that the quality of facilities and infrastructure provided by the Libyan government is bad. This result implied that majority of the respondents were dissatisfied with the quality of facilities and infrastructure services provided by the Libyan government.

Question 5: What is your assessment of the quality of speed of access to service (such as getting official documents) provided by the Libyan government for the citizens?

The result of Question 5 reveals that the mean score for respondents was 3.12. This result shows that majority of the respondents, $54(27 \%)$ and $34(17 \%)$, answers is not good and bad respectively. This result indicate that majority of the respondents estimated that the quality of speed of access to services such as getting official documents was sluggish and poor. This indicated that the citizens suffer from administrative and bureaucratic bottleneck and delay. Therefore, the result implies that the respondents were not satisfied with the quality of the speed of accessing government administrative service.

\section{Question 6: What is your assessment of the quality of employment as provided by the Libyan government for the citizens?}

The result of Question 6 shows that the mean score for respondents' perspective was 3.97. This result shows that majority of the respondents', $82(41 \%)$ and $52(26 \%)$, answers is bad and not good respectively. This implied that the respondents expressed the position that the provision of employment and job for the citizens by the Libyan government was bad. Therefore, the result implied that the respondents have been dissatisfied with the provision of employment services by the Libyan government.

Question 7: What is your assessment of the quality of accommodation service and their unit prices that suit citizens' income as provided by the Libyan government?

On a last note, the result of question 7 indicates that the mean score for respondents was 3.94. This result shows that majority of the respondents', 64 (32\%) and 68 (34\%), answers is bad and not good respectively. In other words, this answer suggests that respondents expressed the view that the quality of accommodation provided for the citizens and the prices in relations with income of citizens is not satisfactory. Therefore, the result implied that the respondents expressed dissatisfaction over the position as it relates to the quality, adequacy, and prices of accommodation provided for citizens by the Libyan government.

As a result, the general average to answer questions was 3.64 from $1=$ excellent to $5=$ bad. This explains that most of the respondents' perspective has tended to the agreement on the poor public service quality which was provided by the government to the people. This result provide the answer to the question of the study: What is the Libyan people assessment of public service quality provided by Libyan government? Also, it 
achieves the objective of the study: to declare Libyan people's assessment of public service quality provided by Libyan government.

Table 2. Descriptive Statistics for Respondents' Perspective on Public Services Quality
$\mathrm{N}=200$
Minimum $=1$
Maximum $=5$

\begin{tabular}{|c|c|c|c|c|c|c|c|c|c|c|c|c|c|c|}
\hline \multirow[t]{2}{*}{ The question } & \multirow[t]{2}{*}{ Mean } & \multicolumn{4}{|c|}{ Frequency } & \multicolumn{8}{|c|}{ Percentage } & \multirow{2}{*}{\begin{tabular}{|c} 
Mea \\
$\mathrm{n}$ of \\
all \\
Qs
\end{tabular}} \\
\hline & & $\overline{1}$ & 2 & & & 4 & 5 & 1 & 2 & 3 & & & 5 & \\
\hline $\begin{array}{l}\text { 1. What is your assessment of } \\
\text { a health service quality which } \\
\text { is provided by the Libyan } \\
\text { government for the citizens? }\end{array}$ & 3.36 & 2 & 52 & 60 & 44 & & 42 & 1 & 26 & 30 & 22 & & 21 & \\
\hline $\begin{array}{l}\text { 2. What is your assessment of } \\
\text { the quality of education which } \\
\text { is provided by Libyan } \\
\text { government for the citizens? }\end{array}$ & 3.23 & 2 & 60 & 54 & 58 & & 26 & 1 & 30 & 27 & 29 & & 13 & \\
\hline $\begin{array}{l}\text { 3. What is your assessment of } \\
\text { the quality of justice and } \\
\text { public security service which } \\
\text { is provided by the Libyan } \\
\text { government for the citizens? }\end{array}$ & 3.72 & 2 & 32 & 54 & 44 & & 68 & 1 & 16 & 27 & 22 & & 34 & \\
\hline $\begin{array}{l}\text { 4. What is your assessment of } \\
\text { the quality of facilities and } \\
\text { infrastructure which is } \\
\text { provided by the Libyan } \\
\text { government for the citizens? }\end{array}$ & 4.16 & 4 & 12 & 32 & 46 & & 06 & 2 & 6 & 16 & 23 & & 53 & 3.64 \\
\hline $\begin{array}{l}\text { 5. What is your assessment of } \\
\text { the quality of speed of access } \\
\text { to services (such as getting } \\
\text { official documents) provided } \\
\text { by the Libyan government for } \\
\text { the citizens? }\end{array}$ & 3.12 & 6 & 26 & 60 & 5 & & 34 & 3 & 23 & 30 & 27 & & 17 & \\
\hline $\begin{array}{l}\text { 6. What is your assessment of } \\
\text { the quality of employment as } \\
\text { provided by the Libyan } \\
\text { government for the citizens? }\end{array}$ & 3.97 & 2 & 18 & 46 & 52 & & 82 & 1 & 9 & 23 & 26 & & 41 & \\
\hline $\begin{array}{l}\text { 7. What is your assessment of } \\
\text { the quality of accommodation } \\
\text { services and their unit prices } \\
\text { that suit the citizens' income } \\
\text { as provided by the Libyan } \\
\text { government? }\end{array}$ & 3.94 & 0 & 8 & 60 & 68 & & 64 & 0 & 4 & 30 & 34 & & 32 & \\
\hline
\end{tabular}

Note 1; Scale for Answering; 1= Excellent; $2=$ Good; 3= Neutral; 4= Not Good; 5= Bad

\section{Discussion}

The Libyan governmental administration suffers from numerous and continuous changes in the body laws at short periods, and this often resulted in the poor application of the laws. This encouraged the weakness of 
the accountability mechanism of the state and that of government institutions. Consequently, this led to the emergence of many problems in the management of the public sector in providing public services. Some of the noted problems include bias in the implement of administrative law, widespread corruption, bribery, nepotism, and cronyism.

This position was confirmed by the General Planning Council, GPC, in Libya when it pointed out that there is weakness of accountability and the failure of legislative, administrative and functional laws and rules to keep pace with international developments in the field of public administration (GPC, 2004). The position was also expounded by Abu Baker Mustafa (2007) when he noted that the problems that confronted the implementation of development policies within the Libya administration over the past decades have affected the Libyan state. He noted that the adoption of the principle of politics and loyalty as guide for the selection of administrative leadership in government, regardless of the ability of these leaders to achieve their tasks, is a contradiction of the labor laws regarding appointment into position within the public sector in Libya. Weakness of the adoption of the rule of law in the administration of state affairs resulted in weakness of accountability processes for each negligent in providing good service to citizens. This has led to the spread of various forms of corruption which has resulted to the failure of most public institutions in the provision of good service.

The respondents emphasized that they suffer from poor quality of services provided by the Libyan government. They pointed out that most of the public services provided by the government are less than those required as it relates to quality and quantity. Through the answers of the respondents, it is clear that the state is interested in the security sector with disregards for other sectors such as health, education, infrastructure, accommodation, and governmental procedures. This has made the operation of the government to lack in the rule of law. This is because it leads to weakness of the accountability of institutions that provide services that are not good. Thus, if the government had adhered to the faithful application of the rule of law, which will be to assist in achieving good governance procedures in the conducts of its activities and operations, it would have impacted positively on each sector of the administration of the state.

Moreover, the world has come to take the development of any country in terms of the quality of life of its citizens. To measure development from the angle of the quality of life of citizens, the international community has adopted a living index called the quality of life index. The quality of life index is based on the measuring of the quality of government performance as it relates to good public administration and the provision of better services to citizens. This is predicated on the cost of living, provision of comfort and culture, the growth of the economy, caring for the environment, provision of good public health system, good infrastructure, low risk, provision of security, climatic conditions, and other standards which relies on reports from several international organizations competent to assess the levels of health and the economy, as well as reports from UNESCO and a number of other international organizations. Due to the lack of reliable data for Libya, Table 3 shows Libya rank in the quality of life index for selected years.

\section{Table 3. Libya Rank in the Quality of Life Index for Selected Years}

\begin{tabular}{ccccc}
\hline The dimension & $\mathbf{2 0 1 0}$ & $\mathbf{2 0 1 1}$ & $\mathbf{2 0 2 0}$ & $\mathbf{2 0 2 1}$ \\
\hline Cost of Living & 29 & 72 & 70.80 & 51.93 \\
Leisure \& Culture & 50 & 59 & -- & -- \\
Economy & 52 & 58 & 43.48 & -- \\
Environment & 51 & 29 & 41.33 & -- \\
Freedom & 0 & 0 & 34.27 & -- \\
Health & 71 & 52 & 68.42 & 47.67 \\
Infrastructure & 44 & 21 & 30.55 & -- \\
\hline
\end{tabular}

It is clear from the table above that the rank of Libya in the quality of life index is almost consistent with the view of the respondents. The rate of security is the best, while the rate for other indicators is not at the 
required level. In the same vain, the rate for freedom is zero and this is because the previous political system does not allow for freedom of expression as anyone who criticizes the system is liable to be punished and there is also the lack of freedom of press. Undoubtedly, the situation as it relates to the low ranking for Libya in the life index reflects the crisis of severe waste of wealth and the distortion of the spending priority. This situation has led to the enhancement of the spread of corruption in various sectors of the state, within the apparatuses of government, and the personnel of the government from the highest to the lowest level. However, after the rising of the political system in 2011, the freedom is better than before. As a result of the above, it is evident that public services provided by the Libyan government to the citizens are still poor in quality.

\section{Recommendation}

6.1 There is need to ensure the independence of the legislative institution via the constitution of the state. The power of legislative independence should cover freedom to issue appropriate laws, review previous laws and policies of governments that may run contrary to the task of enhancing democratization and popular participation.

6.2 Ensure the independence of the judiciary in order to enhance the ability of the institution to work freely without pressure from the government. Enhancing the power and independence of the judiciary is strengthening the supremacy of the law, and this guarantees the elimination of bias even in cases against senior government officials. Also, it strengthens citizens' beliefs that no abuse will occur without punishment.

6.3 Public service, which is the main objective of any government, is to provide public services quality to citizens and protect their interests. However, from the evidence of the results of analysis on the quality of public services in Libya, it becomes apparent that this goal has not been a priority of the Libyan government. Therefore, to improve the quality of public services provided by the Libyan government, the following suggestions are made:

There is the need to review the priorities and objectives of the government as it relates to the provision of quality of public services. This review should be conducted through the development of plans and programmes aimed at improving the delivery of public quality services to citizens using the easiest possible means.

6.4 Adopting of E-government in the conduct of government business. E-government procedures can be deployed as tool in achieving the targets of comprehensive and sustainable development.

6.5 There is need to encourage the establishment of organizations that work to preserve the rights of citizens to obtain high quality of public services such as consumer protection organizations.

\section{Conclusion}

Based on the results of the analysis conducted and elaborated before, several conclusions can be drawn as follows :

Despite the fact that quality of life is one of the most important elements of prosperity in any society, the Libyan society through this study showed that most of the citizens look to the existing laws and policies of governments which are not effective in forcing the governments and various institutions to provide good quality services. This justifies that the view of the majority of the respondents about the quality of public services was not good.

\section{References}

1. Ahmad, N. A. (2015). Exploring service quality and customer satisfaction at library in Malaysia University. International Journal of Administration and Governance, pp. 98-105.

2. Al Haddad, A. (2009). Corruption and Sustainable Development. Analytical Vision of the Reality of the Phenomenon in Libya. Accessed February 2, 2009, from http://www.libyaalyoum.com/news/index.php?id=21\&textid=3378 \&(p.7.(

3. Al Haddad, A. (2009). Sustainable development and corruption. An analytical view of the phenomena in Libya. 
4. Betamer, A. (2003). The efficiency of administrative leadership of the fundamental requirements for improving the quality of the public sector in Libya. Conference of The public administration in Libya: actually and ambitions Tripoli, Economic Sciences Research Center, October 11-12. 2003.

5. Chapman, R. A. (2000). Ethics in Public Service for the New Millennium. Publisher; Ashgate.

6. General Planning Council in Libya (GPC) (2004). Prospects for development and administrative development in Libya. Accessed from; http://www.npc.gov.ly/tshre3a1t.html.

7. Husin, N. A. (2015). Toward a greater understanding of how service quality drives students' satisfaction in higher learning institutions. International Journal of Administration and Governance, pp. 9-13.

8. Mokhlis, S. A. (2011). Municipal Service Quality and Citizen Satisfaction in Southern Thailand. Journal of Public Administration and Governance, pp. 122-137.

9. Mokhlis, S. A. (2011). Municipal Service Quality and Citizen Satisfaction in Southern Thailand. Journal of Public Administration and Governance, pp. 122-137.

10. Mustafa, A. \& Abu Bakr, A. (2007). The General Environment of the development of managerial from the perspective of good governance. The first national conference for the development and management training in Libya, Tripoli: National Institute of Administration.

11. Mustafa, A. \& Abu Bakr, A. (2008). There is no Development without Sustainable Management Stewardship. Sustainable Development Conference in Libya.

12. Mustafa, A. \& Abu Bakr, A. (2007). The overall environment for the development of administrative from the perspective of good governance, the First National Conference for the development and of administrative training in Libya, Tripoli: National Institute of Management.

13. Obeidi, A. (2004). Libyan Security Policy between Existence and Feasibility: an Exploratory Study, University Of Garyounis-Benghazi, press.

14. Ramserook-Manhurrun, P. L.-B. (2010). Service quality in the public services. International Journal of Management and Marketing Research, pp. 37-50.

15. Ramserook-Manhurrun, P. L. B. (2010). Service quality in the public services. International Journal of Management and Marketing Research, pp. 37-50.

16. Rotberg, R. I. (2004). Strengthening governance: ranking countries would help, The Washington Quarterly 28(1), (pp, 71-81).Ulusoy, A. (2004). Qualify for Public Service Inc. Istanbul, Country Books 